\title{
Changes in land use in the buffer zone of lake of the Mała Wełna catchment
}

\author{
Mariusz Ptak ${ }^{1}$, Agnieszka E. Ławniczak ${ }^{2}$ \\ ${ }^{1}$ Institute of Physical Geography and Environmental Planning, Adam Mickiewicz University, Dzięgielowa 27, 61-680 Poznań, Poland; \\ e-mail: marp114@wp.pl \\ ${ }^{2}$ Department of Ecology and Environmental Protection, Poznań University of Life Sciences, Piątkowska 94C, 60-649 Poznań, Poland; \\ e-mail: lawnic@up.poznan.pl
}

\begin{abstract}
One of the most important elements in the protection of water quality is buffer zones. In order to protect water quality, appropriate management of these areas is necessary. In the paper, changes in the land use in the buffer zone of $200 \mathrm{~m}$ width around lakes in the Mała Wełna catchment over 20 years were analysed. For the study eight lakes larger than 50 ha were chosen. Changes in the land use within the buffer zone were studied from 1980 to 2000, based on topographic maps in the scale 1:10 000. Results show both positive and negative aspects of land changes. An increase in forested areas and grasslands through tilled land were positive aspects of these changes. On the other hand, the enhancement of suburban development in these zones caused increased probability of water pollution from these areas. Calculations of potential nutrient loading from different types of land use in these zones indicated an enhancement of nutrient sources in the lakes within the 20-year study period. However, these changes are not significant in comparison to the nutrient loads contributed by the tributaries. Our study indicated that in the case of flow lakes, more important is an improvement in water quality in the tributaries and a reduction in nutrient sources in the catchment with the purpose of reducing the input of nutrients into the lake. Management of the buffer zone is one of the issues which have to be taken into consideration in lake protection after elimination of the major water pollutant sources.
\end{abstract}

Key words: riparian zone, nutrient loading, eutrophication

\section{Introduction}

Most lakes in Poland are characterized by low water quality. This condition is derived from changes that occur in the lakes causing degradation of the water quality. An increase in human population accompanying the development of all economic sectors caused a catastrophic situation in lake degradation. Moreover, in opposition to rivers, lakes have mostly lotic water and their exchange is rather slow (Choiński 2007), which particularly enables accumulation of different types of pollutants.

One-way human activity, in its assumptions, ignored the environment and the possibility of losing its qualitative and quantitative traits. At the end of the 20th century this problem began to be acknowledged. Construction of new sewage treatment plants influenced the reduction in pollution, particularly from point sources. Another equally important issue is the non-point nutrient pollution sources, mainly from agriculture. At present, nitrogen loading from arable fields is one of the biggest sources of water pollutants. Marszelewski (1993) indicated significant differences in the extent of contamination of north-eastern and western Polish lakes. This division is a result of the adaptation of the central and western part of the country to agriculture production, which entailed a substantial area of deforestation.

One of the most effective methods to protect water ecosystems against nutrient pollution is a proper and efficient usage of land located next to the lake shoreline. This zone plays a crucial role in the reduction in nutrient loading to the water bodies. Many studies have studied buffer zones (Kasprzak 1986; Hillbricht-Ilkowska; Wiśniewski 1993; Hanowski et al. 2002; Anbumozhi et al. 2003; Hillbricht-Ilkowska 1997, 2005; Schmieder 2004; Ławniczak and Bartusz 2010), among others, in the aspect of their functioning and management. However, recognition of changes in land use over longer periods is crucial for the protec- 
tion and management of lakes. It is particularly important in the catchment where agricultural pressure is very high.

The aim of the study was to present the current structure of land use in the buffer zone of selected lakes in the lowland river catchment. Secondly, changes in land use in the buffer zones over 20 years were analysed. Subsequently, consequences of land use changes for potential nutrient loading to lakes were studied.

\section{Study sites}

The buffer zones of eight lakes (lake surface $>50$ ha) located in the Mała Wełna River catchment were studied (Fig.1).

The Mała Wełna catchment is a typical agricultural area, where forests and other types of land use cover very small areas. The studied catchment is also characteristic for Wielkopolska region, where there is a predominance of small rivers subjected to high human pressure, particularly agricultural (Kupiec at al. 2008, Ławniczak et al. 2008). Basic morphological traits of the studied lakes are presented in Table 1.

All of the lakes studied are characterized by high susceptibility to degradation (Choiński 2006; WIOŚ 2008). This is mostly caused by shallow depth and unfavourable land use in their catchments.

\section{Methods}

Land use in the buffer zones was studied based on cartographic materials: topographic maps in the scale 1:10 000 from two periods: about 1980 and 2000. A buffer zone of $200 \mathrm{~m}$ around each lake was designated. The area covered by different types of land use within these zones was determined and calculated for each period.

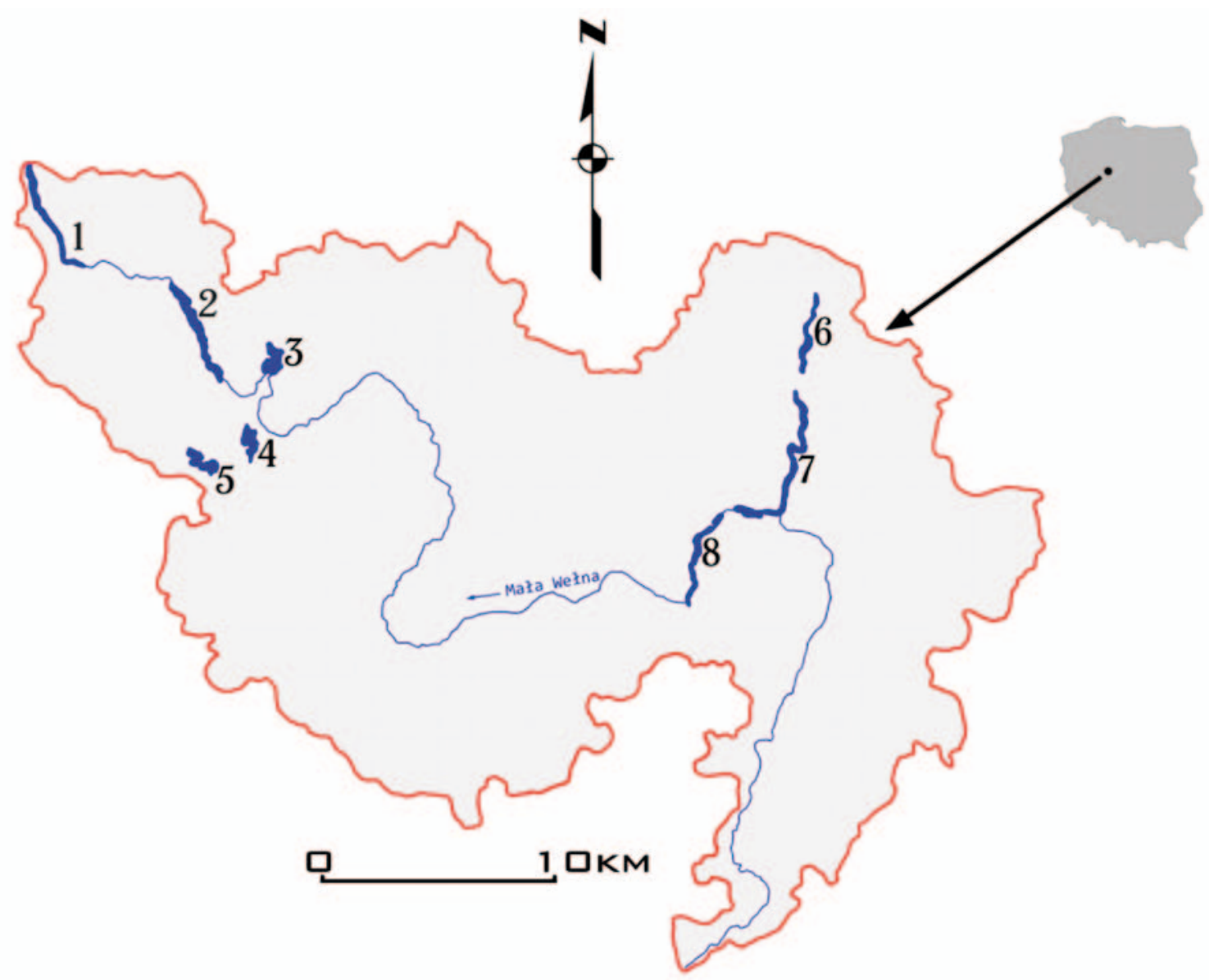

Fig. 1. Localisation of lakes larger than 50 ha in the Mała Wełna catchment (1 - Rogoźno, 2 - Budziszewskie, 3 - Rościńskie, 4 - Maciejak, 5 - Brzeźno, 6 - Łopienno, 7 - Kłeckie, 8 - Gorzuchowskie) 
Table 1. Morphometric traits of lakes more than 50 ha, situated in the Mała Wełna catchment

\begin{tabular}{|c|c|c|c|c|}
\hline \multirow{2}{*}{ Lake } & Surface ${ }^{*}$ & Average depth** & Volume $^{* *}$ & Shoreline length $^{* * *}$ \\
\hline & [ha] & {$[\mathrm{m}]$} & {$\left[\mathrm{dam}^{3}\right]$} & {$[\mathrm{m}]$} \\
\hline Budziszewskie & 155.0 & 4.8 & 7842.9 & 10025 \\
\hline Kłeckie & 141.0 & 4.7 & 8432.7 & 16025 \\
\hline Rogoźno & 131.0 & 3.0 & 3808.5 & 10925 \\
\hline Gorzuchowskie & 98.5 & 2.5 & 2371.3 & 8625 \\
\hline Rościńskie & 70.0 & 2.8 & 2157.3 & 4400 \\
\hline Maciejak & 62.5 & 2.7 & 2645.5 & 4550 \\
\hline Włókna & 62.5 & 3.2 & 2414.4 & 5675 \\
\hline Łopienno & 57.5 & 6.1 & 3869.1 & 7175 \\
\hline
\end{tabular}

* Choiński (2006), ${ }^{* *}$ IRŚ (Choiński 2006), ${ }^{* * *}$ Jańczak (1996)

Based on the measured areas and indices of the annual nutrient leaching from different types of areas, the potential nutrient loading to each lake was estimated. Values of annual nutrient leaching from different types of areas used in this study are presented in Table 2. Phosphorus loads resulting from the catchment land use were compared to the permissible and excessive loads estimated on the hydraulic model of Vollenweider et al. (1980).

Table 2. Indices of the annual nutrient leaching from different types of areas according to Kajak (1979), Rydling and Rast (1989), Giercuszkiewicz-Bajtlik (1990) after Bajkiewicz-Grabowska (2002)

\begin{tabular}{|l|r|r|}
\hline \multirow{2}{*}{\multicolumn{1}{|c|}{ Land use }} & $\mathrm{N}$ & \multicolumn{1}{c|}{$\mathrm{P}$} \\
\cline { 2 - 3 } & {$\left[\mathrm{kg} \mathrm{N} \mathrm{ha}^{-1} \mathrm{yr}^{-1}\right]$} & \multicolumn{1}{c|}{$\left[\mathrm{kg} \mathrm{P} \mathrm{ha}^{-1} \mathrm{yr}^{-1}\right]$} \\
\hline Woodlands & 6.5 & 0.2 \\
\hline Meadows and pasture & 8 & 0.3 \\
\hline Built-up areas (compact) & 6 & 0.9 \\
\hline Built-up areas (casual) & 9.3 & 5.3 \\
\hline Arable fields & 10.1 & 0.56 \\
\hline Fallow lands & 8 & 0.3 \\
\hline Scrub and shrubs & 6.5 & 0.2 \\
\hline Wetlands & 6.5 & 0.2 \\
\hline
\end{tabular}

\section{Results and discussion}

The studied buffer zones of eight lakes in the Mała Wełna catchment were dominated by arable lands or woodland. The highest percentage of tilled land in the buffer zones was observed in Gorzuchowskie and Łopienno lakes (more than 50\% of the total area) in both study periods (Table 3). Zones of the Rogoźno, Maciejak and Bodziszewskie lakes had the largest area covered by forest (more than 60\%). The highest increase in suburban development was observed in the surrounding areas of Rogoźno and Gorzuchowskie lakes.

Analyses of total changes in the buffer zones of all studied lakes between the two periods have shown a decrease in areas covered by tilled fields, shrubs, wetlands and fallow lands (Fig. 2). Other forms of land use increased over 20 years. However, the biggest changes were noted in suburban development (an increase of $56 \%$ for compact suburban development, and of $24 \%$ for casual suburban development). An increase in forest, grasslands and open water of $3 \%, 5 \%$ and $17 \%$, respectively, was detected.

Table 3. Ripparian zone land use [ha] in the Mała Wełna catchment in the year 1980 and 2000

\begin{tabular}{|c|c|c|c|c|c|c|c|c|c|c|c|c|c|c|c|c|c|c|}
\hline \multirow[t]{2}{*}{ Lake } & \multicolumn{2}{|c|}{ Woodlands } & \multicolumn{2}{|c|}{$\begin{array}{l}\text { Meadows and } \\
\text { pasture }\end{array}$} & \multicolumn{2}{|c|}{$\begin{array}{l}\text { Built-up areas } \\
\text { (compact) }\end{array}$} & \multicolumn{2}{|c|}{$\begin{array}{l}\text { Built-up areas } \\
\text { (casual) }\end{array}$} & \multicolumn{2}{|c|}{ Arable fields } & \multicolumn{2}{|c|}{$\begin{array}{l}\text { Scrub and } \\
\text { shrubs }\end{array}$} & \multicolumn{2}{|c|}{ Water } & \multicolumn{2}{|c|}{ Wetlands } & \multicolumn{2}{|c|}{ Fallow lands } \\
\hline & 1980 & 2000 & 1980 & 2000 & 1980 & 2000 & 1980 & 2000 & 1980 & 2000 & 1980 & 2000 & 1980 & 2000 & 1980 & 2000 & 1980 & 2000 \\
\hline Budziszewskie & 188.4 & 180.1 & 9.8 & 9.6 & 1.8 & 2.1 & 7.1 & 15.7 & 2.3 & 2.1 & -1 & - & & -1 & 1.6 & 1.4 & - & - \\
\hline Kłeckie & 99.2 & 102.1 & 27.2 & 29.7 & 5.7 & 9.2 & 0.7 & 1.9 & 102.4 & 91.9 & 2.3 & 2.5 & $7.4(1)$ & $7.5(\mathrm{I})$ & 1.0 & 1.1 & - & - \\
\hline Rogoźno & 125.5 & 131.9 & 15.4 & 18.9 & 25.1 & 34.1 & 3.8 & 8.7 & 36.9 & 17.3 & 14.3 & 11.1 & $1.6(p)$ & $0.2(p)$ & 2.8 & 3.2 & - & 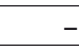 \\
\hline Gorzuchowskie & 3.9 & 4.0 & 40.2 & 30.2 & 15.3 & 18.6 & - & - & 119.2 & 123.3 & 6.1 & 5.2 & $0.5(p)$ & $1.0(p)$ & 0.8 & 3.9 & 1.5 & 1.3 \\
\hline Rościńskie & 27.7 & 36.5 & 30.7 & 41.1 & - & - & 0.8 & 0.9 & 25.7 & 6.4 & 3.0 & 2.9 & $0.5(p)$ & $0.5(p)$ & 0.3 & 0.4 & - & \\
\hline Maciejak & 72.3 & 74.8 & 4.9 & 4.6 & - & - & 0.8 & 2.8 & 4.1 & 3.6 & 0.6 & 2.1 & $3.6(1)$ & $6.9(I)$ & 10.3 & 1.8 & - & - \\
\hline Włókna & 32.5 & 39.3 & 18.2 & 20.3 & - & - & 4.7 & 8.4 & 31.6 & 22.1 & 1.0 & 1.4 & $\begin{array}{l}1.0(I) \\
0.1(p)\end{array}$ & $\begin{array}{l}2.0(\mathrm{l}) \\
0.3(\mathrm{p})\end{array}$ & 9.6 & 4.9 & - & - \\
\hline Łopienno & 19.0 & 18.0 & 23.3 & 24.2 & 9.6 & 11.7 & 0 & 1.9 & 77.5 & 73.3 & 6.4 & 8.0 & $1.8(1)$ & $1.5(\mathrm{I})$ & 1.8 & 1.9 & 2.1 & 1.0 \\
\hline$\Sigma$ & 568.5 & 586.7 & 169.7 & 178.6 & 57.5 & 75.7 & 17.9 & 40.3 & 399.7 & 340.0 & 33.7 & 33.2 & 16.5 & 19.9 & 28.2 & 18.6 & 3.6 & 2.3 \\
\hline
\end{tabular}

(l) - lakes, (p) - ponds 

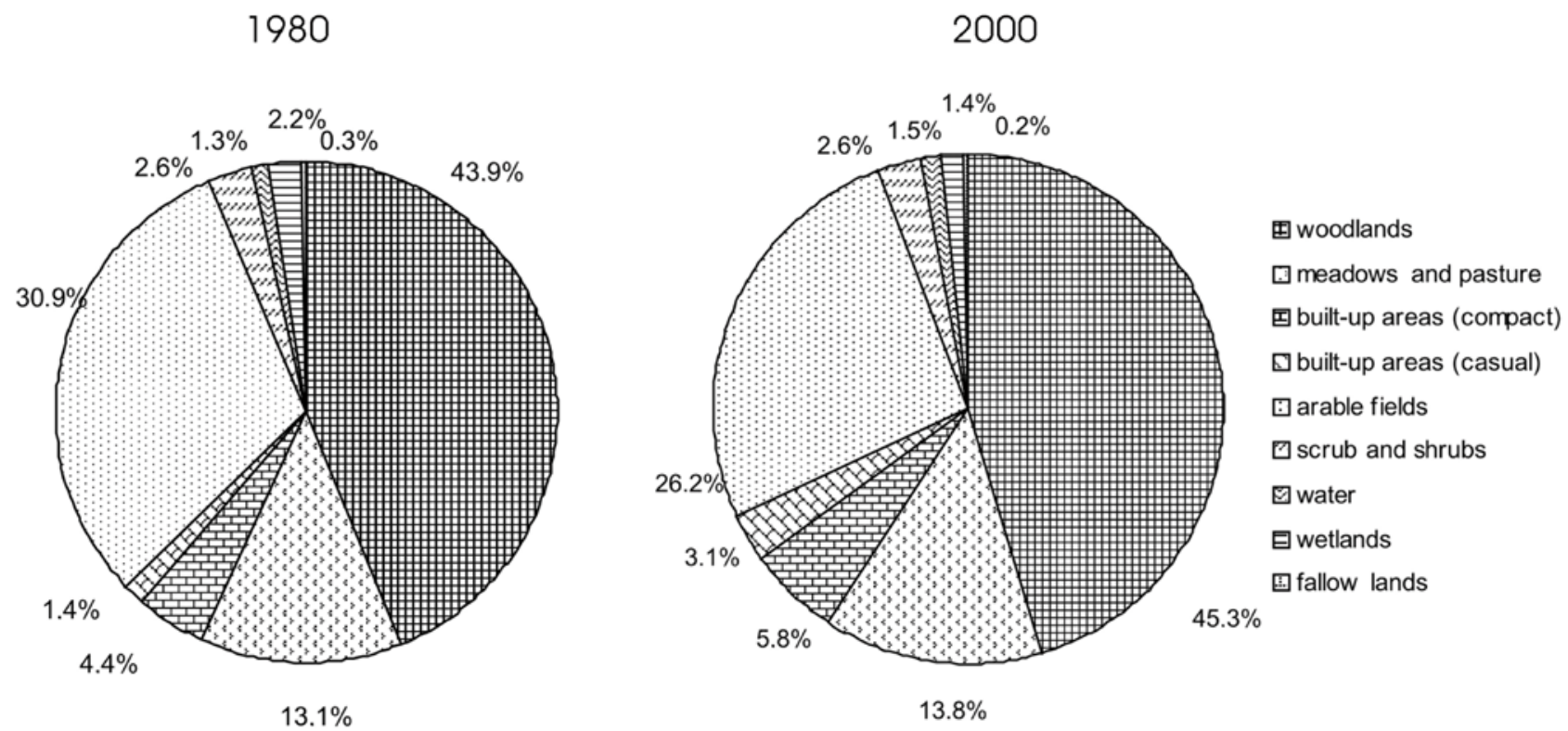

Fig. 2. Percentage of different land use of the buffer zones of the studied lakes in the Mała Wełna catchment

Taking into consideration the character of areas acting as a buffer zone to pollution inflows, according to Dąbrowska-Prot and Hillbricht-Ilkowska (1991), Hillbricht-Ilkowska (1991, 1997) and Mozgawa (1995), these zones can be divided into the following types:

- areas of high importance; such as a buffer zone in relation to nutrients transported with water. Different types of wetlands belong to this category (bog, fen, marshes)

- buffer areas of moderate impact; mostly grasslands, pastures, forest

- "non-buffer" systems; arable lands, built-up areas.

According to the divisions presented above, our results indicated that changes which occurred in the studied buffer zone had both positive and negative characteristics. A positive aspect of these changes is an increase in forested area, grasslands and open water. Within open water, the most significant enhancement of the area was observed in respect to ponds (by $67.9 \%$ ) and lakes (by 39.6\%). However, most of these ponds are intensively used by fishermen. One of the most important transformations was the decrease in arable land by $18 \%$ of the total zone area.

In total, the forested area increased in six lakes, grassland area increased in five lakes, arable land increased in seven zones, shrubs and trees increased in four zones, and wetland area increased in five zones. The most adverse changes concern an increase in compact and casual suburban development (by $31.6 \%$ and $25.1 \%$, respectively), a decrease in scrubs and shrubs by $1.5 \%$, wetlands by $34.1 \%$ and a reduction in fallow lands by $36.2 \%$. The most isolated lake from pollutant leaching from open areas in the catchment in both studied periods was Lake Budziszewskie, where more than $89 \%$ of the total area was covered by woodlands. The most unfavourable structure of land use was Lake Łopienno, where above $50 \%$ of the buffer area was covered by tilled land. Moreover, Lake Budziszewskie, despite the favourable buffer zone management system, was characterized by poor water quality (WIOŚ 2008). This result indicates that major nutrient pollution does not come from non-point agricultural sources, but probably also from tourist resorts located in the buffer zone of this lake. The localization of tourist resorts next to the lake carries a serious threat for water quality. Churski (1988) observed a deterioration in water quality in the Brodnickie Lakeland due to pressure of the tourist infrastructure and inappropriate wastewater management in the catchments. The most desirable transformation should be considered in the land use structure of the buffer zone observed in Lake Rościńskie (Fig. 3). Over 20 years, an increase in forest area, grasslands and wetlands of $30 \%$ and a reduction in tilled land of more than $70 \%$ were noted.

In contrast, the most unfavourable changes were observed in the buffer zone of Lake Maciejak (Fig. 4) which increased the threat of water degradation. A reduction in wetland area of more than $80 \%$, in grasslands of $6 \%$ and an increase in suburban development of more than $200 \%$ were evidence of strong pressure 


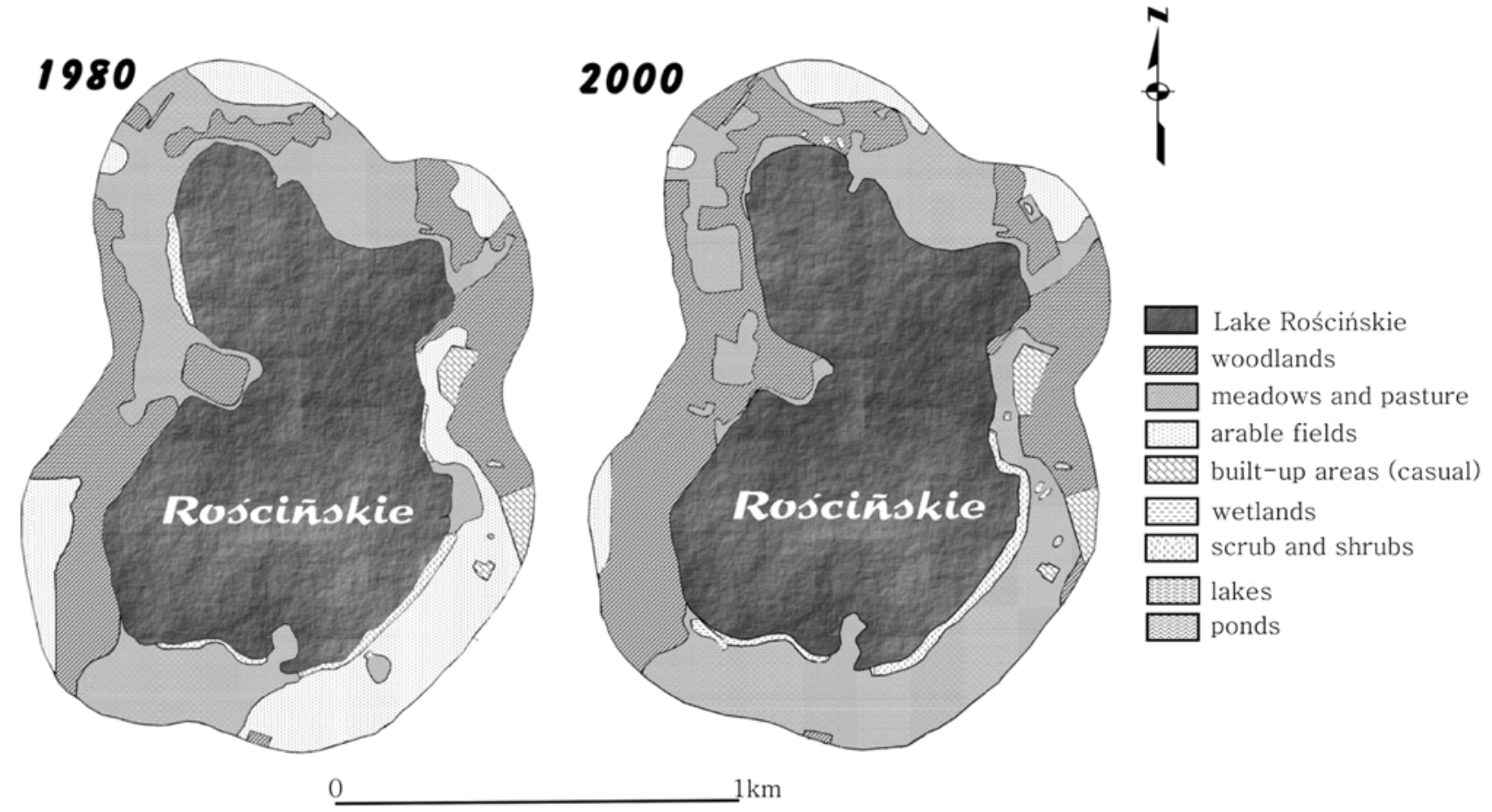

Fig. 3. Land use of the buffer zone of Lake Rościńskie in the years 1980 (A) and 2000 (B)
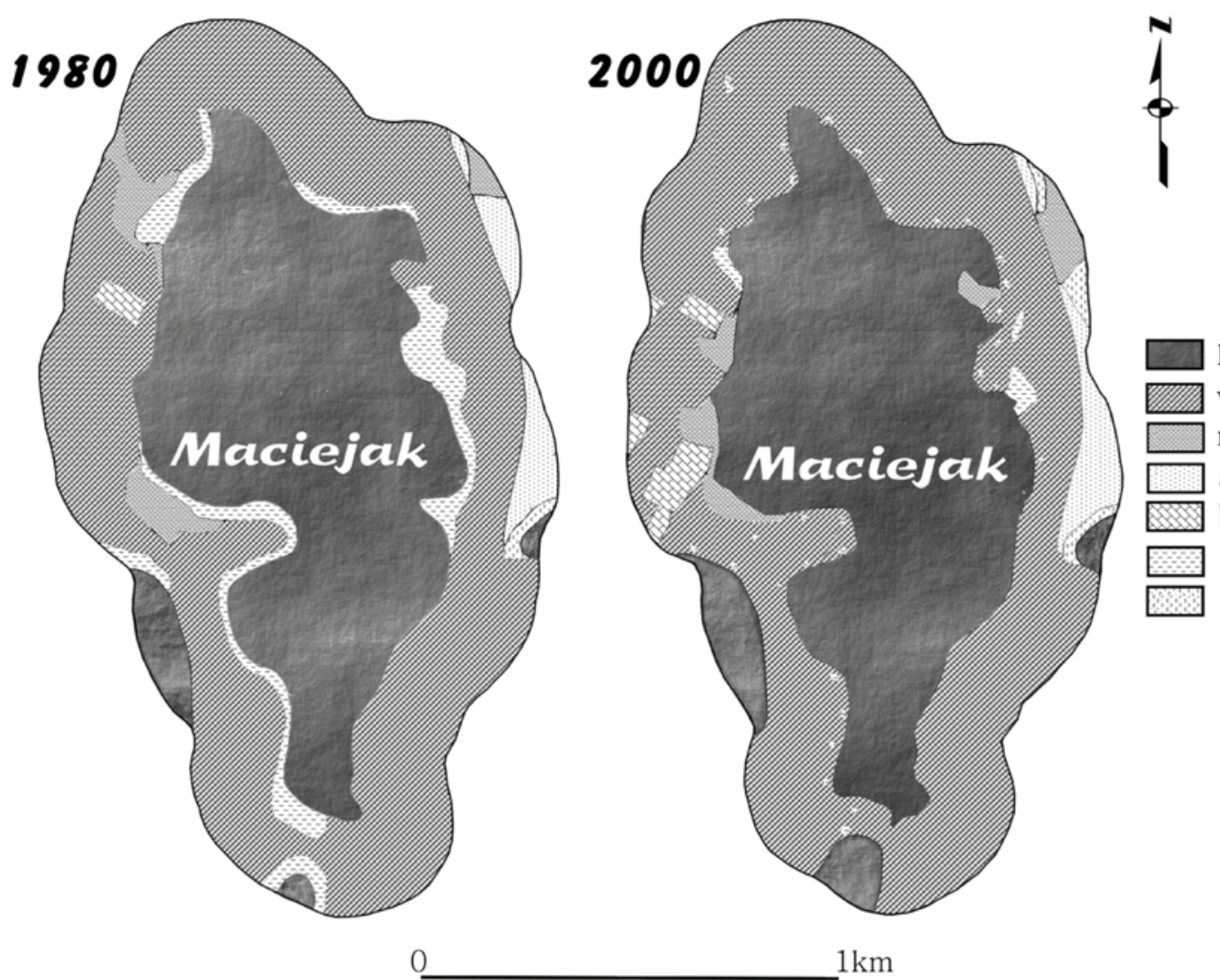

lakes

woodlands

meadows and pasture arable fields built-up areas (casual) wetlands scrub and shrubs

Fig. 4. Land use of the buffer zone of Lake Maciejak in the years 1980 (A) and 2000 (B) 
on the lake ecosystem. Such a large reduction in wetland indicates drainage of the riparian zone. This situation probably occurs due to an increase in water level in the lake of $0.3 \mathrm{~m}$. From the point of view of water resources it is a positive phenomenon. However, increased lake surface occurred at the expense of wetland areas which could accumulate a high amount of nutrient flow from the lake catchment. In the context of protection of lake water quality, loss of wetlands is very unfavourable.

Further investigation will be necessary with a view to recognizing the impact of the increased water level in the lake on wetland development as well as on the lake's ecosystem. Ławniczak et al. (2010) showed the negative effect of water level reduction on macrophyte growth in Lake Niepruszewskie. These results can suggest a positive effect of the increase in water level on water quality. However, many factors can negatively influence lake functioning; for example, the flooding of nutrient rich areas, which may be a significant source of nutrients.

The consequence of land use changes in Lakes Gorzuchowskie and Rogoźno was increased potential nutrient loading from the buffer zone to these lakes
(Table 4 and 5). Based on the nutrient export coefficients from the catchment, it can be shown that the significant increase in built-up areas in the buffer zones of Rogoźno lake enhanced phosphorus loading by $18 \%$ (Table 4 ). Increased forested areas in the buffer zones of Rościńskie lake results in a reduction in potential nitrogen loading on average by $8.2 \%$ and phosphorus loading by $24 \%$ (Table 4 and 5). Taking into consideration all studied areas, changes in land use caused a slight reduction in nitrogen (by $2 \%$ ) and enhanced phosphorus loading (by $11 \%$ ) to the lakes (Fig. 5 and 6). However, in this type of analyses each lake needs to be studied individually.

However, analyses of phosphorus loads, calculated per lake square meter, resulting from the catchment land use showed slight differences within the two studied periods. These values were lower than permissible and there were excessive loads of phosphorus in each lake, except for Lake Łopienno (Table 6). The estimated values of phosphorus loads in Lake Łopienno were higher than permissible, but lower than excessive P loads, classifying this lake as class II risk. Taking into consideration the calculated values of $\mathrm{P}$ loads for each lake, the land use changes in the buffer zones of the

Table 4. Phosphorus loading $\left(\mathrm{kg} \mathrm{P} \mathrm{yr}^{-1}\right)$ from different types of land use in the buffer zones of the studied lakes in the Mała Wełna catchment in the year 1980 and 2000

\begin{tabular}{|c|c|c|c|c|c|c|c|c|c|c|c|c|c|c|c|c|c|c|}
\hline \multirow[t]{2}{*}{ Lake } & \multicolumn{2}{|c|}{ Woodlands } & \multicolumn{2}{|c|}{$\begin{array}{l}\text { Meadows and } \\
\text { pasture }\end{array}$} & \multicolumn{2}{|c|}{$\begin{array}{c}\text { Built-up areas } \\
\text { (compact) }\end{array}$} & \multicolumn{2}{|c|}{$\begin{array}{l}\text { Built-up areas } \\
\text { (casual) }\end{array}$} & \multicolumn{2}{|c|}{ Arable fields } & \multicolumn{2}{|c|}{ Fallow lands } & \multicolumn{2}{|c|}{$\begin{array}{l}\text { Scrub and } \\
\text { shrubs }\end{array}$} & \multicolumn{2}{|c|}{ Wetlands } & \multicolumn{2}{|c|}{ Total } \\
\hline & 1980 & 2000 & 1980 & 2000 & 1980 & 2000 & 1980 & 2000 & 1980 & 2000 & 1980 & 2000 & 1980 & 2000 & 1980 & 2000 & 1980 & 2000 \\
\hline Budziszewskie & 37.6 & 36.02 & 1.96 & 1.92 & 0.36 & 0.42 & 1.42 & 3.14 & 0.46 & 0.42 & 0 & 0 & 0 & 0 & 0.32 & 0.28 & 42.12 & 42.20 \\
\hline Kłeckie & 19.84 & 20.42 & 5.44 & 5.94 & 1.14 & 1.84 & 0.14 & 0.38 & 20.48 & 18.38 & 0 & 0 & 0.46 & 0.5 & 0.2 & 0.22 & 47.70 & 47.6 \\
\hline Rogoźno & 25.1 & 26.38 & 3.08 & 3.78 & 5.02 & 6.82 & 0.76 & 1.74 & 7.38 & 3.46 & 0 & 0 & 2.86 & 2.22 & 0.56 & 0.64 & 44.76 & 45.04 \\
\hline Gorzuchows & 0.78 & 0.8 & 8.04 & 6.04 & 3.06 & 3.72 & 0 & 0 & 23.84 & 24.66 & 0.3 & 0.26 & 1.22 & 1.04 & 0.16 & 0.78 & 37.40 & 37.30 \\
\hline Rościńskie & 5.54 & 7.3 & 6.14 & 8.22 & 0 & 0 & 0.16 & 0.18 & 5.14 & 1.28 & 0 & 0 & 0.6 & 0.58 & 0.06 & 0.08 & 17.64 & 17.64 \\
\hline Maciejak & 14.46 & 14.96 & 0.98 & 0.92 & 0 & 0 & 0.16 & 0.56 & 0.82 & 0.72 & 0 & 0 & 0.12 & 0.42 & 2.06 & 0.36 & 18.60 & 17.94 \\
\hline Włókna & 6.5 & 7.86 & 3.64 & 4.06 & 0 & 0 & 0.94 & 1.68 & 6.32 & 4.42 & 0 & 0 & 0.2 & 0.28 & 1.92 & 0.98 & 19.52 & 19.28 \\
\hline Łopienno & 3.8 & 3.6 & 4.66 & 4.84 & 1.92 & 2.34 & 0 & 0.38 & 15.5 & 14.66 & 0.42 & 0,2 & 1.28 & 1.6 & 0.36 & 0.38 & 27.90 & 28.00 \\
\hline
\end{tabular}

Table 5. Nitrogen loading $\left(\mathrm{kg} \mathrm{N} \mathrm{yr}^{-1}\right)$ from different types of land use in the buffer zones of the studied lakes in the Mała Wełna catchment in the year 1980 and 2000

\begin{tabular}{|c|c|c|c|c|c|c|c|c|c|c|c|c|c|c|c|c|c|c|}
\hline \multirow[t]{2}{*}{ Lake } & \multicolumn{2}{|c|}{ Woodlands } & \multicolumn{2}{|c|}{$\begin{array}{l}\text { Meadows and } \\
\text { pasture }\end{array}$} & \multicolumn{2}{|c|}{$\begin{array}{l}\text { Built-up areas } \\
\text { (compact) }\end{array}$} & \multicolumn{2}{|c|}{$\begin{array}{c}\text { Built-up areas } \\
\text { (casual) }\end{array}$} & \multicolumn{2}{|c|}{ Arable fields } & \multicolumn{2}{|c|}{ Fallow lands } & \multicolumn{2}{|c|}{$\begin{array}{l}\text { Scrub and } \\
\text { shrubs }\end{array}$} & \multicolumn{2}{|c|}{ Wetlands } & \multicolumn{2}{|c|}{ Total } \\
\hline & 1980 & 2000 & 1980 & 2000 & 1980 & 2000 & 1980 & 2000 & 1980 & 2000 & 1980 & 2000 & 1980 & 2000 & 1980 & 2000 & 1980 & 2000 \\
\hline Budziszewskie & 1224.6 & 1170.7 & 63.7 & 62.4 & 11.7 & 13.7 & 46.2 & 102.1 & 15.0 & 13.7 & 0 & 0 & 10.4 & 9.1 & 0 & 0 & 1371.6 & 1371.7 \\
\hline Kłeckie & 644.8 & 663.7 & 176.8 & 193.1 & 37.1 & 59.8 & 4.6 & 12.4 & 665.6 & 597.4 & 15.0 & 16.3 & 6.5 & 7.2 & 0 & 0 & 1550.4 & 1549.9 \\
\hline Rogoźno & 815.8 & 857.4 & 100.1 & 122.9 & 163.2 & 221.7 & 24.7 & 56.6 & 239.9 & 112.5 & 93.0 & 72.2 & 18.2 & 20.8 & 0 & 0 & 1454.9 & 1464.1 \\
\hline Gorzuchowskie & 25.4 & 26.0 & 261.3 & 196.3 & 99.5 & 120.9 & 0 & 0 & 774.8 & 801.5 & 39.7 & 33.8 & 5.2 & 25.4 & 9.8 & 8.5 & 1215.7 & 1212.4 \\
\hline Rościńskie & 180.1 & 237.3 & 199.6 & 267.2 & 0 & 0 & 5.2 & 5.9 & 167.1 & 41.6 & 19.5 & 18.9 & 2.0 & 2.6 & 0 & 0 & 573.5 & 573.5 \\
\hline Maciejak & 470.0 & 486.2 & 31.9 & 29.9 & 0 & 0 & 5.2 & 18.2 & 26.7 & 23.4 & 3.9 & 13.7 & 67.0 & 11.7 & 0 & 0 & 604.7 & 583.1 \\
\hline Włókna & 211.3 & 255.5 & 118.3 & 132.0 & 0 & 0 & 30.6 & 54.6 & 205.4 & 143.7 & 6.5 & 9.1 & 62.4 & 31.9 & 0 & 0 & 634.5 & 626.8 \\
\hline Łopienno & 123.5 & 117.0 & 151.5 & 157.3 & 62.4 & 76.1 & 0 & 12.4 & 503.8 & 476.5 & 41.6 & 52.0 & 11.7 & 12.4 & 13.7 & 6.5 & 908.2 & 910.2 \\
\hline
\end{tabular}




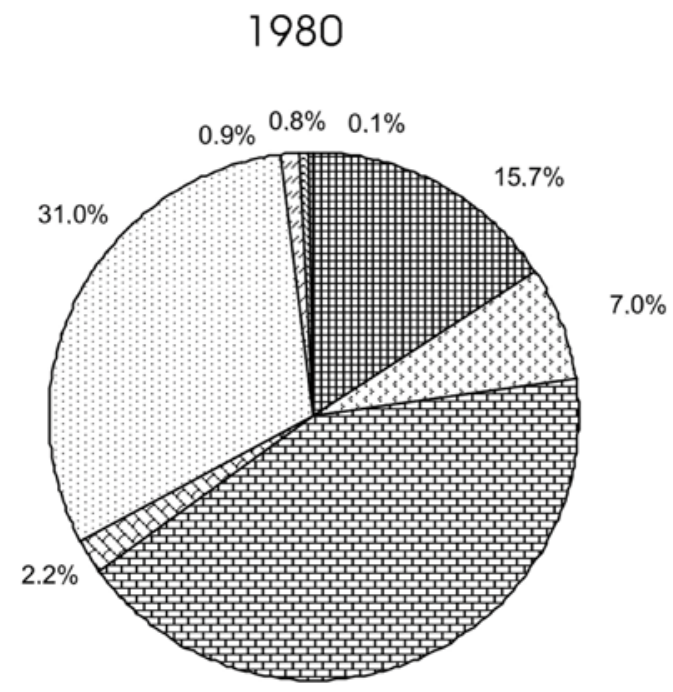

$42.2 \%$

\section{0}

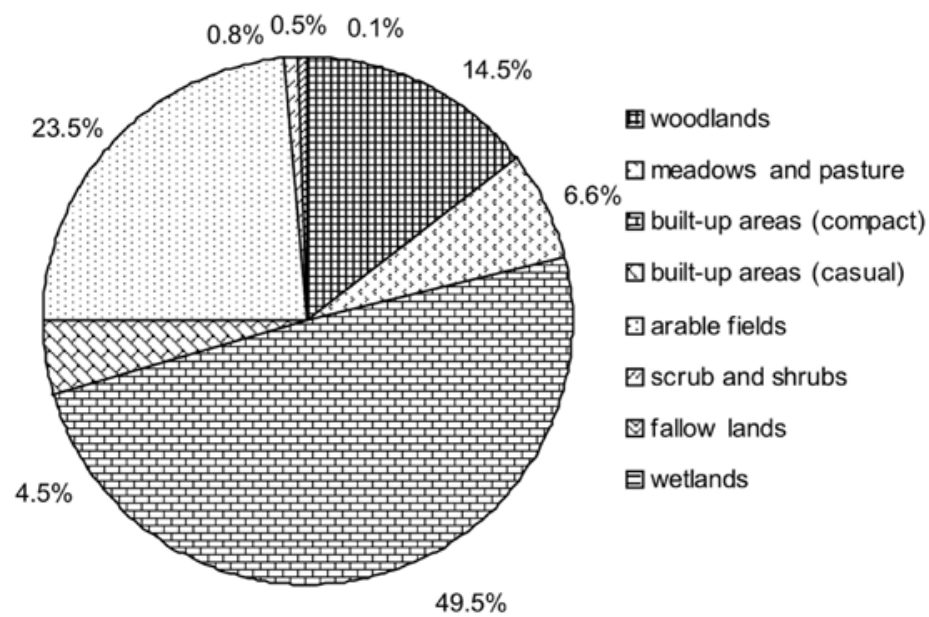

Fig. 5. Percentage differences of phosphorus loading from buffer zones of all studied lakes due to changes in land use

1980

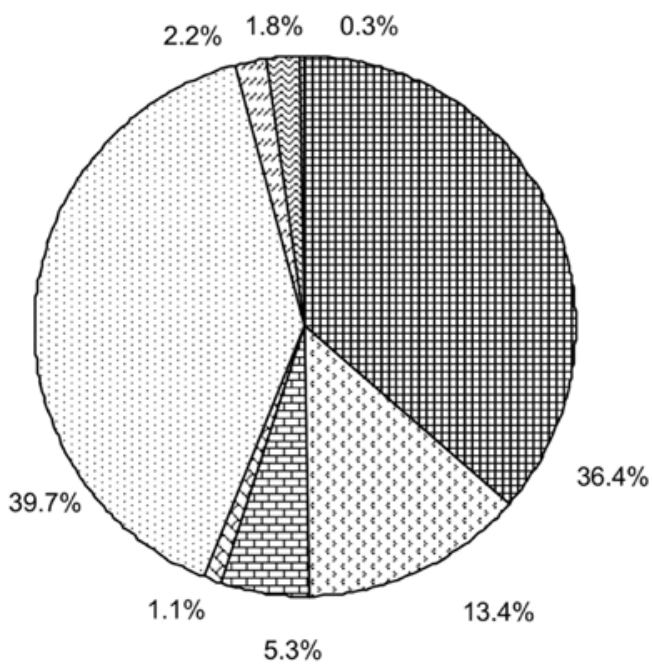

2000

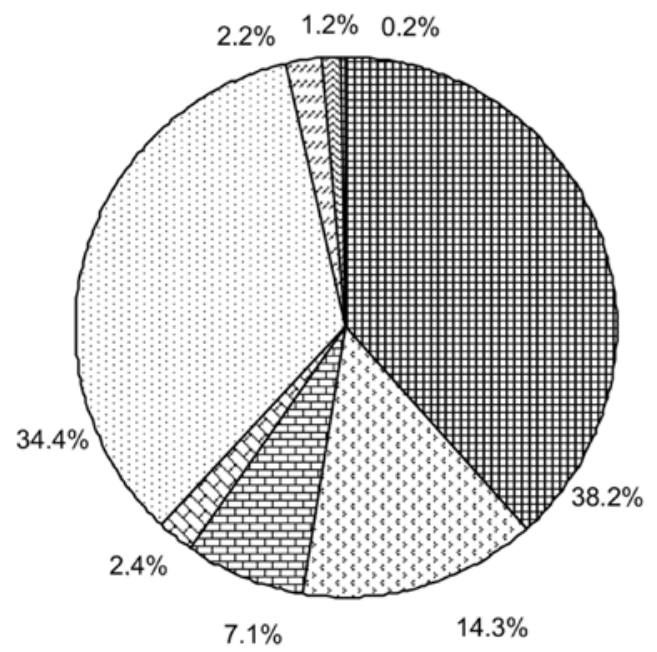

团 woodlands

$\square$ meadows and pasture

国built-up areas (compact)

$₫$ built-up areas (casual)

$\square$ arable fields

Ð scrub and shrubs

囚 fallow lands

曰 wetlands

Fig. 6. Percentage differences of nitrogen loading from buffer zones of all studied lakes due to changes in land use

Table 6. Risk levels of the analysed lakes based on phosphorus loads from different types of land use in the buffer zones of the studied lakes in the Mała Wełna catchment in the year 1980 and 2000 in comparison to permissible and excessive phosphorus loads for each lake

\begin{tabular}{|c|c|c|c|c|c|}
\hline \multirow{3}{*}{ Lake } & 1980 & 2000 & Permissible & Excessive & \multirow{3}{*}{ Risk level } \\
\hline & P load & P load & load & load & \\
\hline & $\mathrm{mg} \mathrm{P} \mathrm{m}^{-2}$ & $\mathrm{mg} \mathrm{P} \mathrm{m}^{-2}$ & $\mathrm{mg} \mathrm{P} \mathrm{m}^{-2}$ & $\mathrm{mg} \mathrm{P} \mathrm{m}^{-2}$ & \\
\hline Budziszewskie & 27.2 & 27.2 & 145.0 & 290.0 & I \\
\hline Kłeckie & 33.8 & 33.8 & 48.7 & 97.4 & I \\
\hline Rogoźno & 34.2 & 34.4 & 252.3 & 504.6 & I \\
\hline Gorzuchowskie & 38.0 & 37.9 & 130.1 & 260.2 & 1 \\
\hline Rościńskie & 25.2 & 25.2 & 356.6 & 713.2 & I \\
\hline Maciejak & 29.8 & 28.7 & 49.8 & 99.5 & I \\
\hline Włókna & 31.2 & 30.8 & 55.8 & 111.6 & I \\
\hline Łopienno & 48.6 & 48.7 & 29.4 & 58.7 & II \\
\hline
\end{tabular}


studied lakes did not entail drastic and large enhancements of nutrient loads into the lakes.

\section{Conclusions}

The subordination of human activity in the catchment in order to protect water quality of lakes and rivers is not possible. This issue is therefore purely theoretical. In particular, this applies to highly degraded areas used for agriculture; as exemplified by the Mała Wełna watershed. Therefore, such an important issue is the appropriate management in areas located directly next to water bodies (Hefting 2003). Changes in the studied buffer zones show that this issue is complex. In buffer zones of eight lakes, positive and negative directions of changes in the aspect of water quality protection were observed. Within selected types of land use, the most important is to increase woodland and grassland areas. This observation is supported by the study of Hefting (2003), who observed a reduction in nitrogen in the water in the buffer zone covered by mown grasslands and forest. A simultaneous reduction in tilled land and increasing forested areas and grasslands may successfully increase the availability of buffer zones against nutrient pollution. This direction of transformation has been observed recently; however, mostly in the zone with low soil valuation. In this situation, economic calculation is the main cause of positive changes. Moreover, the management of these areas for suburban development is a serious threat.

The concentration of buildings in the lakes' buffer zones without efficient sewage systems is particularly dangerous. As indicated by the study of Ławniczak et al. (2010), a concentration of sewage treatment plants in the lake buffer zone may cause nutrient leaching into the lakes. Not renewing sewage treatment plants after a few years can play a significant role in non-point nutrient sources causing water quality degradation. Also, through bad storage of pollutants (eg, defective septic tanks) nutrients can be transported to the water bodies through groundwater.

A quantifiable assessment of changes in land use structure over 20 years was possible due to a comparison of possible nutrient leaching from different types of land use. Although this analysis gives approximate results, it better shows consequences of changes in land usage in the buffer zones. The obtained results indicate the importance of controlling changes in the riparian zone of lakes in the aspect of their protection. Estimation of the possible nutrient loading to lakes from different types of land use also gives the opportunity to recognize the directivity of changes in the buffer zone of lakes and to take action to better protect the lake ecosystem.

Moreover, the role of buffer zones and types of land use in lake catchments on water quality in lakes is not questionable, but in the case of flow lakes inlets are frequently the most important sources of nutrient pollution (Bajkiewicz-Grabowska 2002; Ławniczak et al. 2010; Kanclerz 2011). The studied lakes are connected by the Mała Wełna River, which is characterized by high nutrient concentrations (Murat-Błażejewska 2001, Murat-Błażejewska and Sojka 2005). Furthermore, the water of Mała Wełna is also polluted by fish ponds located at the Kiszkowo cross-section (Kanclerz 2005). Thus, in this case other sources of nutrient pollutants than nutrient loads from different types of land use in the catchments had the most significant influence on water quality in the studied lakes.

Our analyses have shown difficulties in lake protection and management in the buffer zone of lakes. However, management of the buffer zone is one of the issues which have to be taken into consideration in lake protection. In the case of flow lakes it is necessary to improve water quality in the tributaries and to reduce all nutrient sources in the catchment with the aim of reducing the input of nutrients into the lake. Management of the buffer zone is one of the issues which have to be taken into consideration in lake protection after elimination of the major water pollutant sources. Then, reasonable action and appropriate protection reduces nutrient loading to lakes, which causes long term reduction in expenses related to possible lake recultivation.

\section{References}

Anbumozhi V., Purwanto M.Y.J. Sutoyo S., 2003, Effects of riparian landuse practices on water environment in West Java, Indonesia, J. Ecol. Environ. Sci. 29 (2): 131 136.

Bajkiewicz-Grabowska E., 2002, Obieg materii w ekosystemach rzeczno-jeziornych (Circulation of matter in the river-lake systems), Wyd. UW, Warszawa, p. 274 (in Polish, English summary).

Choiński A., 2006, Katalog jezior Polski (Catalogue of Polish lakes), Wyd. Nauk. UAM, Poznań, p. 600 (in Polish).

Choiński A., 2007, Limnologia fizyczna Polski (Physical limnology of Poland), Wyd. Nauk. UAM, Poznań, p. 540 (in Polish). 
Churski Z., 1988, Wpływ gospodarczej działalności człowieka na zmiany jezior i mokradeł na Pojezierzu Brodnickim (Influence of human economic activity on the lakes and wetlands in the Brodnica Lake District), [in:] Churski Z. (ed.), Naturalne i antropogeniczne przemiany jezior i mokradeł w Polsce (Natural and anthropogenic transformations of lakes and wetlands in Poland), Wyd. UMK, Toruń. 182-194 (in Polish).

Dąbrowska-Prot E., Hillbricht-Ilkowska A., 1991, Struktura i funkcjonowanie krajobrazu pojeziernego: próba ekologicznego spojrzenia, kierunki ochrony (The structure and functioning of a Lake District Landscape: An attempt at an ecological approach, guidelines for protection), Zesz. Nauk. Kom. Nauk "Człowiek i środowisko" PAN 15: 237- 249 (in Polish, English summary).

Jańczak J. (ed.), 1996, Atlas jezior Polski. T. 1: Jeziora Pojezierza Wielkopolskiego i Pomorskiego w granicach dorzecza Odry (The atlas of Polish lakes. Vol. 1: Wielkopolska and Pomeranian Lake Districts in the Odra River basin), Bogucki Wyd. Nauk., Poznań, p. 268 (in Polish, English summary).

Hefting M., 2003, Nitrogen transformation and retention in riparian buffer zones [Dissertation], Proefschrift Universiteit Utrecht, Utrecht, p. 197.

Hillbricht-Ilkowska A., 1991, Funkcjonowanie obszarów młodoglacjalnych o szczególnych walorach przyrodniczych (The functioning of early post-glacial areas of particular natural value), [in:] Mazur S. (ed.) Ekologiczne podstawy gospodarowania środowiskiem przyrodniczym: wizje, problem, trudności (The ecological basis of environmental management: visions, problems, difficulties), Wyd. SGGW, Warszawa, 153-170 (in Polish).

Hillbricht-Ilkowska A., 1997, Ekologiczne problemy gospodarowania jakością wód powierzchniowych oraz ich siedliskiem i przyrodą (The ecological problems of surface waters quality, habitat and wildlife management), Zesz. Nauk. Kom. Nauk „Człowiek i Środowisko” PAN 17: 63-88 (in Polish, English summary).

Hillbricht-Ilkowska A., 2005, Ochrona jezior i krajobrazu pojeziernego - problemy, procesy, perspektywy (The protection of lakes and lakeland landscape - problems, processes, perspectives), Kosmos 54(2-3): 285-302.

Hillbricht-Ilkowska A., Wiśniewski R.J., 1993, Trophic differentiation of lakes of the Suwalki Landscape Park (north-eastern Poland) and its buffer zone - present state, changes over years, position in trophic classification of lakes, Ekol. Pol.41(1-2): 195-219.

Kajak Z., 1979, Eutrofizacja jezior (Eutrophication in lakes), Wyd. PWN, Warszawa, p. 232 (in Polish).

Kanclerz J., 2011, Wpływ Jeziora Gorzuchowskiego na jakość wód rzeki Małej Wełny (The influence of Lake Gorzuchowskie on water quality in the Mała Wełna river), Nauka Przyr. Technol. 5(5) \#82 (in Polish, English summary).
Kanclerz J., 2005, Wpływ stawów rybnych (karpiowych) na jakość wód odpływających ze zlewni (The impact of Carp Fish Ponds on quality of outflow water from the catchment). Mat. VII Ogólnopol. Konf. Nauk. „Kompleksowe i szczegółowe problemy inżynierii środowiska": Koszalin-Ustronie Morskie 26-29 maj, Wyd. PKoszal., Koszalin-Ustronie Morskie, \#62: 1-10 (in Polish, English summary).

Kasprzak K., 1986, Roślinność jako bariera w biologicznej ochronie wód (Plants as a barrier in the biological conservation of waters), Kronika Wielkopolski 2 (41): 52-79 (in Polish).

Kupiec J., Ławniczak A.E., Zbierska J., 2008, Action reducing the outflow of nitrates from agricultural sources to waters on the nitrate vulnerable zone in the catchment of the Samica Stęszewska river, Ann. Warsaw Univ. of Life Sciences-SGGW, Land Reclam. 40: 3-13.

Ławniczak A.E., Bartusz A., 2010, Zmiany struktury użytkowania stref przybrzeżnych jezior poddanych silnej antropopresji (Changes in land use structure of the riparian zones of lakes subjected to strong anthropogenic pressure), [in:] Choiński A. (ed.) Przemiany jezior i zbiorników wodnych (Transformations of lakes and water reservoirs), Bogucki Wyd. Nauk., Poznań: 77-88 (in Polish, English summary).

Ławniczak A.E., Zbierska J., Andrzejewska B., 2010, Bilans biogenów Jeziora Tomickiego (Nutrient balance of Tomickie Lake), Rocz. Ochr. Srod. 12: 861-878 (in Polish, English summary).

Ławniczak A.E., Zbierska J., Choiński A., Szczepaniak W., 2010, Response of emergent macrophytes to hydrological changes in a shallow lake, with special reference to nutrient cycling, Hydrobiologia 656: 243-254.

Ławniczak A.E., Zbierska J., Kupiec J., 2008, Changes of nutrient concentrations in water sensitive to nitrate pollution from agricultural sources in the Samica Stęszewska river catchment, Ann. Warsaw Univ. of Life SciencesSGGW, Land Reclam. 40: 15-25.

Marszelewski W., 1993, Zmiany zanieczyszczenia jezior (Lake pollution changes), [in:] Dynowska I. (ed.) Przemiany stosunków wodnych $\mathrm{w}$ Polsce $\mathrm{w}$ wyniku procesów naturalnych i antropogenicznych (Transformation of water conditions in Poland as a result of natural and anthropogenic processes), Wyd. UJ, Kraków, 148-165 (in Polish).

Mozgawa J., 1995, Zastosowanie zdjęć lotniczych do charakterystyki ekotonalności i mozaikowości krajobrazu na przykładzie krajobrazów północno-wschodniej Polski (The use of aerial photographs for the purpose of characterization of landscape ecotones and mosaic makeup, based on the landscapes of North-Eastern Poland), Zesz. Nauk. Kom. Nauk. "Człowiek i środowisko" PAN 12: 15-26 (in Polish, English summary). 
Murat-Błażejewska S., 2001, Czasowe i przestrzenne zmiany jakości wód małych cieków nizinnych (na przykładzie rzeki Małej Wełny) (Temporal and spatial changes of water quality in small lowland water-courses (on the example of Mała Wełna River)), Mat. V Ogólnopol. Konf. Nauk. „Kompleksowe i szczegółowe problemy inżynierii środowiska": Koszalin-Ustronie Morskie 21-24 maj, Wyd. PKoszal., Koszalin-Ustronie Morskie: \# 49: 693-702 (in Polish, English summary).

Murat-Błażejewska S., Sojka M., 2005, Ocena jakości zasobów wodnych rzeki Małej Wełny dla potrzeb bilansu wodno-gospodarczego (Evaluation of water resources quality of Mała Wełna River for water-economic balance requirements), Mat. VII Ogólnopol. Konf. Nauk. „Kompleksowe i szczegółowe problemy inżynierii środowiska": Koszalin-Ustronie Morskie 26-29 maj, Wyd. PKoszal., Koszalin-Ustronie Morskie, \#60: 1-10 (in Polish, English summary).
Ryding S.O., Rast W. (eds), 1989, The control of eutrophication of lakes and reservoirs. Man and the Biosphere Series. Vol. 1, UNESCO and Parthenon Publishing, Paris, p. 314.

Schmieder K., 2004, European lake shores in danger - concepts for a sustainable development, Limnologica 34 (12): 3-14.

Vollenweider R.A., Rast W., Kerekes J.J., 1980, The phosphorus loading concept and Great Lakes eutrophication, [in:] Loehr R.C., Martin C., Rast W. (eds.), Phosphorus management strategies for lakes, Interscience, Ann Arbor: 207-234.

[WIOŚ] Wojewódzki Inspektorat Ochrony Środowiska w Poznaniu, 2008, Raport o stanie środowiska przyrodniczego w Wielkopolsce w roku 2008 (The Report on the state of the environment in Wielkopolska in 2008), Bibl. Monit. Środ., Poznań, p. 107 (in Polish). 